\title{
Genetic characterization of tambaqui stocks from two pisciculture stations in the lower São Francisco River
}

\section{Caracterização genética de estoques de tambaqui de duas estações de piscicultura no baixo rio São Francisco}

\author{
Edmara Ramos Melo ${ }^{1 *}$; Alany Ítala Pontes Nascimento ${ }^{2}$.Sophia Tenenbaum \\ Bacellar Corrêa ${ }^{1}$; Emerson Carlos Soares ${ }^{3}$; Elton Lima Santos ${ }^{3}$; Valéria Nogueira \\ Machado ${ }^{4}$; Themis Jesus Silva ${ }^{3}$
}

\section{Highlights:}

High levels of genetic diversity were found in the two fish farms.

AMOVA revealed greater within- than between-stock genetic variation.

Reproductive management has been effective in maintaining stock variability.

\begin{abstract}
Pisciculture has been an important part of the economy in many regions of Brazil, and the tambaqui (Colossoma macropomum) stands out as one of the country's most commercialized native freshwater fish species. Loss of genetic variability can affect characteristics such as reproduction and growth rates, as well as disease resistance and is of great concern in this field. Molecular markers such as mitochondrial DNA genes have been increasingly used to understand genetic variability in species of economic importance. This study aimed to characterize the genetic variability of tambaqui populations reared in two fish farms (Itiúba, AL and Betume, SE) of the lower São Francisco River by analyzing the control region and ATPase genes of mitochondrial DNA. Sequencing of samples from progenies and breeding individuals identified 42 haplotypes (32 unique), of which four haplotypes were shared between the two fish farms as a result of a founder effect, because-individuals from Itiúba formed the stock of the Betume fish farming Station. Haplotype diversity was high in both locations. Analysis of Molecular Variance (AMOVA) revealed greater genetic variation within populations $(96.76 \%)$ than between them (3.24\%) and the $\mathrm{F}_{\mathrm{ST}}$ value (0.03) indicated low genetic differentiation between the two populations. The observed high genetic variability can be explained by the number of breeders in the two fish farms (200 in Itiúba and 1400 in Betume) and the breeding management system, which seems to be effective in maintaining stock variability.
\end{abstract}

Key words: ATPase. Colossoma macropomum. Control region. Genetic variability.

1 Engas de Pesca, Universidade Federal de Alagoas, UFAL, Penedo, AL, Brasil. E-mail: edmara-melo@hotmail.com; sophiatbc@ hotmail.com

2 Discente do Curso de Mestrado do Programa de Pós-Graduação em Diversidade Biológica e Conservação nos Trópicos, UFAL, Maceió, AL, Brasil. E-mail; alanypontes@gmail.com

3 Profs. Drs., Centro de Ciências Agrárias, UFAL, Rio Largo, AL, Brasil. E-mail: soaemerson@gmail.com; elton@zootecnista. com.br; themisjdasilva@gmail.com

$4 \operatorname{Prof}^{\mathrm{a}} \mathrm{Dr}^{\mathrm{a}}$, Universidade Estadual do Amazonas, UEA, Manaus, AM, Brasil. E-mail: valeria.pesca@gmail.com

* Author for correspondence 


\begin{abstract}
A piscicultura tem ocupado um lugar de destaque na economia de muitas regiões do Brasil, e o tambaqui (Colossoma macropomum) se sobressai por ser uma das espécies nativas de peixes de água doce mais comercializadas do país. A diminuição da variabilidade genética pode afetar características como as taxas de reprodução e crescimento, bem como resistência a doenças e é de grande preocupação nesse ramo. Marcadores moleculares, como os genes do DNA mitocondrial, vem sendo cada vez mais utilizados para investigar a variabilidade genética em espécies de importância econômica. Assim, este estudo teve como objetivo caracterizar a variabilidade genética de populações de tambaqui cultivados em duas pisciculturas (Itiúba, AL e Betume, SE) do baixo Rio São Francisco, utilizando a região controle e os genes da ATPase do DNA mitocondrial. O sequenciamento de amostras de progênies e reprodutores identificou 42 haplótipos (32 únicos). Destes, quatro haplótipos foram compartilhados entre as duas pisciculturas estudadas, o que é resultado de um efeito fundador, uma vez que indivíduos de Itiúba foram levados para compor o estoque da Estação de Piscicultura de Betume. A diversidade haplotípica foi alta em ambas as localidades. Análise de Variância Molecular (AMOVA) demonstrou maior variação genética dentro das populações $(96.76 \%)$ do que entre elas $(3.24 \%)$ e o valor de Fst $(0.03)$ indicou pouca diferenciação genética entre as duas populações analisadas. A alta variabilidade genética encontrada pode ser explicada pelo número de reprodutores nas duas pisciculturas $(200 \mathrm{em}$ Itiúba e 1400 em Betume) e o manejo reprodutivo, que parece ser eficaz na manutenção da variabilidade de estoques.
\end{abstract}

Palavras-chave: ATPase. Colossoma macropomum. Região controle. Variabilidade genética.

\section{Introduction}

Aquaculture is an industry that has been growing in response to an increasing demand for food. The activity supplies more than $48 \%$ of the world's food fish supply for consumption (Overturf, 2009). One of the main challenges of aquaculture is maintaining the genetic variability of cultivated organisms to minimize inbreeding. To achieve this, the genetic differences between cultivated stock and their wild counterparts must be determined (Liu \& Cordes, 2004) so that the stock, when necessary, can be renewed with individuals from populations with greater genetic variability. Several studies have found differences between native and cultivated stock of tambaqui in different regions of Brazil, highlighting the importance of genetic monitoring of cultivated stock for effective reproductive management and to avoid inbreeding and retain genetic diversity in captivity (F. Gomes et al., 2012; J. P. Aguiar et al., 2013).

The tambaqui, Colossoma macropomum (Cuvier 1818) (Characiformes: Serrasalmidae) (Nelson,
Terry, \& Mark, 2016), is a large freshwater fish that can reach $100 \mathrm{~cm}$ in length and weigh over 30 kg (G. M. Santos, Ferreira, \& Zuanon, 2006). The species is native to the Amazon and Orinoco River basins (Araujo-Lima \& Goulding, 1997) but was introduced to northeastern Brazil in the 1960s by the National Department of Works Against Drought (DNOCS). In 1972, two lots of fry, one from Manaus in the state of Amazonas and the other from Peru, were brought into the Rodolpho Von Ihering Ichthyology Research Center in Pentecoste, state of Ceará (Albuquerque, Silva, \& Kovács, 1991). In 1974, research aimed at breeding the species in captivity began with the goal of populating weirs and creating fattening farms (Molle \& Cadier, 1992). The tambaqui does not reproduce naturally in captivity, requiring the application of hormones to induce spawning (L. de C. Gomes, Simões, \& Araújo-Lima, 2013). In Brazil, C. macropomum is one of the most cultivated freshwater fish along with pacu (Piaractus mesopotamicus) and pirapitinga (Piaractus brachypomus) and its hybrids, with farming concentrated in the Central-West, Northeast, 
and North regions of the country (Ministério da Agricultura, Pecuária e Abastecimento [MAPA], 2019). In 2018, 102.5 thousand tons of tambaqui were produced accounting for $19.7 \%$ of the national fish production. Rondônia is the leading tambaqui producing state in Brazil, whereas Alagoas is the ninth largest producer in the country (Carvalho, 2019).

The success of tambaqui farming is due to many factors, including good adaptability to captivity, firm and flavorful meat, good growth and productivity potential, high rusticity, omnivorous feeding habit, easy reproduction in captivity, resistance to disease, great market acceptance, and production in polyculture systems (Araujo-Lima \& Goulding, 1997).

Owing to the growing economic importance of tambaqui farming, genetic analyses of control region sequences and ATPase 6/8 genes have been conducted to determine the extent of genetic differentiation of the species across its distribution and to investigate the changes in effective population size throughout its evolutionary history (M. C. F. Santos, Ruffino, \& Farias, 2007; M. C. F. Santos, Hrbek, \& Farias, 2018). Studies of mitochondrial genome sequencing (Wu, Xie, He, \& Xie, 2015) and hybrid production (tambatinga and tambacu) have also been done, the latter with the goal of producing economically viable, fast growing strains that are more resistant to disease and temperature variation (Fontes, Senhorini, \& Lucas, 1990).

ATPase 6/8 genes are more conserved than other segments of the mitochondrial DNA such as the control region (DLoop), which is an extremely variable region (Meyer, 1993), and provide valuable genetic markers for monitoring genealogies and variations that occur in progenies (Xin-Hong, ShaoJun, \& Yun, 2004; Yan et al., 2009).

In established farms, the loss of genetic variability is a major concern that is generally associated with the small size of most captive broodstock populations and their high genetic relatedness (Melo et al.,
2006). This genetic relatedness can directly affect various production parameters, including, among others, the diversity of fry to be reared, reproduction potential, production performance, and resistance to disease (Hilsdorf \& Dergam, 1999).

According to Porta, Porta, Martínez-Rodríguez and Alvarez (2006), the effects of management and (reproductive) matrix selection alone can be responsible for a drastic drop in genetic diversity over a single generation. Thus, knowledge of genetic diversity is key for the successful conservation and management of fish farming species.

The use of molecular markers to study commercially important fish and assess genetic variability has been on an upward trend for a long time in Brazil, especially for both wild and captive populations of the tambaqui Colossoma macropomum (M. C. F. Santos et al., 2007, 2018; F. Gomes et al., 2012; J. P. Aguiar et al., 2013; 2018; N.M. Lopera-Barrero et al., 2015; Queiroz, Souza, da Silva, \& Inoue, 2016; Ribeiro et al., 2016; FazziGomes et al., 2017).

M. C. F. Santos et al. (2007) and Fazzi-Gomes et al. (2017) found high genetic variability in natural populations when compared to cultivated stock and little genetic differentiation and high gene flow between populations, indicating that these natural populations form a large panmictic population in the tributary system of the Amazon River. Under farming conditions, stock with low or declining genetic diversity over the generations can lead to inbreeding and a decrease in adaptation to captivity and progeny survival (N.M. Lopera-Barrero et al., 2010; Povh et al., 2008).

Tambaqui pisciculture is a recent activity in the lower São Francisco River with less than 20 years of production (Silva \& Fujimoto, 2012). The Development Agency of the São Francisco and Parnaíba River Valleys (CODEVASF) through Integrated Fisheries Resources and Aquaculture Centers along the São Francisco Valley has contributed to the advancement of Brazilian fish 
farming, especially by supporting the development of techniques and procedures for the artificial propagation (hormonal induction) of several native freshwater species (Faria, Morais, Soranna, \& Sallum, 2013). Among the aquaculture centers, the $4^{\text {th }}$ Regional Superintendence (SR) located in the village of Betume, Neópolis, state of Sergipe (SE) and the Integrated Center of Itiúba (CII) in Porto Real do Colégio, state of Alagoas (AL) support the small local fish farmers by providing fry from the original 1970s DNOCS broodstock.

This study aimed to characterize the genetic variability of tambaqui (Colossoma macropomum) populations in two CODEVASF fish farms located in the cities of Porto Real do Colégio, AL and Neópolis, SE, northeast Brazil using the control region (DLoop) and the ATPase 6/8 genes from mitochondrial DNA to help improve productivity and quality in fish farms of the lower São Francisco River.

\section{Materials and Methods}

Samples from the adipose or caudal fin were collected in 102 tambaqui specimens, 24 breeding individuals from the $4^{\text {th }}$ Regional Superintendence (SR) located in Betume village, SE (10 20'54.12" S 36 31'32.90” W) and 78 (progeny and breeding) individuals from the Integrated Center of Itiúba (CII) in Porto Real do Colégio, AL (10 12' 10.66" $\mathrm{S} 36^{\circ} 41^{\prime} 11.60$ " W). Tissue samples were preserved in $95 \%$ ethanol and stored in a freezer at $-10^{\circ} \mathrm{C}$ in the Molecular Genetics Laboratory at CII. The study was approved by the Federal University of Alagoas (UFAL) Ethics Committee on Animal Use, Brazil $\left(n^{\circ} 09 / 2016\right)$ and followed the ethical guidelines on animal research.

Genomic DNA extraction was done using the Wizard ${ }^{\circledR}$ Genomic DNA Purification Kit (Promega Corporation, Madison, WI, USA) following the manufacturer's instructions. Sample concentration was determined and the quality of the extracted
DNA was analyzed by electrophoresis on a $0.8 \%$ agarose gel.

The control region and ATPase subunits 6 and 8 genes were amplified using the TopTaq Master Mix Kit (Qiagen Biotecnologia Brasil LTDA, São Paulo, SP, Brazil). The primers used for the control region were Chara_LDLoop and Chara_RDLoop (M.C.F. Santos et al., 2018) and for the ATPase genes were ATP 8.2_L8331 and CO3.2_H9236 (Sivasundar, Bermingham, \& Orti, 2001). Each PCR reaction had a total volume of $20 \mu \mathrm{L}$, including $10 \mu \mathrm{L}$ of the Qiagen 2X TopTaq Master Mix PCR Kit, $1.5 \mu \mathrm{L}$ of each primer $(2 \mu \mathrm{M}), 1.5 \mu \mathrm{L}$ of Coral Red Buffer dye solution (10X), $3 \mu \mathrm{L}$ (control region) or $4 \mu \mathrm{L}$ (ATPase) of DNA template (DNA concentration varied between $40-80 \mathrm{ng} / \mu \mathrm{L}$ ), and $2.5 \mu \mathrm{L}$ or 1.5 $\mu \mathrm{L}$ of ultrapure water to complete the control region and ATPase reactions volume, respectively. Amplification conditions were: initial denaturation for $2 \mathrm{~min}$ at $92{ }^{\circ} \mathrm{C}$ followed by 35 denaturation cycles of $1 \mathrm{~min}$ at $93{ }^{\circ} \mathrm{C}$, annealing for $1 \mathrm{~min}$ at 55 ${ }^{\circ} \mathrm{C}$ (control region) or $50^{\circ} \mathrm{C}$ (ATPase), and extension for $2 \mathrm{~min}$ at $72{ }^{\circ} \mathrm{C}$, with final extension at $72{ }^{\circ} \mathrm{C}$ for $5 \mathrm{~min}$. To confirm amplification, PCR products were run on a $1 \%$ agarose gel and compared with the Invitrogen ${ }^{\mathrm{TM}}$ 100-bp DNA Ladder (Invitrogen, Carlsbad, CA, USA).

PCR products with $40 \mathrm{ng} / \mu \mathrm{L}$ or more were sent to Macrogen (Seoul, South Korea) for sequencing, using the CMF2 primer (M.C.F. Santos et al. 2018) for the control region and ATP 8.2_L8331 (Sivasundar et al. 2001), which is specific for the ATPase genes.

Sequence alignment was conducted using the Clustal W program (Thompson, Higgins, \& Gibson, 1994) implemented in BioEdit 7.2.5 (Hall, 1999) and edited manually. After alignment, control region and ATPase fragments were concatenated, generating a single mitochondrial DNA sequence for each individual.

The genetic variability estimates and DNA polymorphism analyses were computed in 
ARLEQUIN 3.5 (Excoffier \& Lischer, 2010) and Dnasp 5.10.1 (Rozas, Librado, Sánchez-Delbarrio, Messeguer, \& Rozas, 2010) based on the number of haplotypes $(\mathrm{H})$, haplotype diversity $(h)$, nucleotide diversity $(\pi)$, and average number of pairwise nucleotide differences $(\mathrm{k})$.

The analysis of molecular variance (AMOVA) was used to examine the genetic differences between and within the localities sampled followed by analysis of pairwise $\mathrm{F}_{\mathrm{ST}}$ values.

To visualize the relationships and distribution of haplotypes between C. macropomum populations, a haplotype network based on the concatenated dataset and a maximum-likelihood (ML) tree generated in RAxML v0.9.0 (Kozlov, Darriba, Flouri, Morel, \& Stamatakis, 2019) was constructed using HaploViewer (Salzburger, Ewing, \& Von Haeseler, 2011).

\section{Results and Discussion}

A 737-bp and a 404-bp fragment were isolated for the ATPase 6/8 genes and the control region (DLoop), respectively, from 84 tambaqui samples (67 from Itiúba and 17 from Betume). Sequencing failed for 18 samples. These fragments were concatenated into a single 1141-bp sequence. The control region sequences were deposited in GenBank (accession numbers KY593611 to KY593620, KY593622 and KY593623, KY593626 to KY593634, KY593637 to KY593654, KY593657 to KY593666, KY593668 and KY593669, KY593671 to KY593674, KY593676, KY593678 to KY593696, and KY593698 to KY593706) and ATPase 6/8 genes sequences were deposited under accession numbers MN 385281 to MN 385364.

Twenty-seven polymorphic sites were identified and the total number of mutations (Eta) was 32, of which 16 were transitions (TS) and 16 transversions (TV). In addition, 42 haplotypes were found, of which 32 were unique and 10 shared. Haplotype 11 (Hap 11) was shared by 17 individuals, followed by haplotypes 05 (Hap 05) and 29 (Hap_29), which were shared by nine and eight individuals, respectively. The most shared haplotypes (Hap 11, Hap 05, and Hap_29) were represented in both sampling sites (Figure 1). The Itiúba site had 36 haplotypes, of which 26 were unique, whereas 10 haplotypes were identified in the Betume site, six of which were unique.

The average nucleotide percentage values were $28.77 \%$ for adenine (A), 30.98\% for cytosine (C), $26.83 \%$ for thymine $(\mathrm{T})$, and $13.41 \%$ for guanine (G). The nucleotide percentage composition revealed an anti-G bias characteristic of the mitochondrial genome (Meyer, 1993), which may be due to selection against the less stable guanine nucleotides on the light strand during mtDNA replication (Clayton, 1982).

The number of mutations in the C. macropomum sequences isolated in this study was 16 transversions and 16 transitions. M. C. F. Santos et al. (2007) analyzed the complete mitochondrial control region of tambaqui specimens from natural populations and found a similar number of transversions (12) but a much larger number of transitions (59) than our study. According to Page and Holmes (1998), transitions are more frequent than transversions because they modify less of the DNA structure. However, according to Meyer (1993), transversions can accumulate slowly and, eventually, exceed the number of transitions simply because there are twice as many possible transversions.

Of the 42 haplotypes identified in the two tambaqui populations, 32 were unique haplotypes. This large number of unique haplotypes can be explained by the high variability of the control region, which accumulates mutations at a greater rate than the ATPase genes (Rogers \& Harpending, 1992). The four haplotypes shared between the two populations may be due to the fact that individuals from the Itiúba population were brought into the Betume fish farm to compose its stock. Conversely, F. Gomes et al. (2012) analyzed the control region 
of 93 tambaqui individuals from 10 fish farms located in the North and Northeast regions of Brazil and found only two haplotypes, indicative of low genetic variability for a cultivation system. A similar pattern of low haplotype diversity was reported by J. da P. Aguiar et al. (2018) in a study that compared wild and cultivated tambaqui populations from across Brazil. These results suggest that a very small number of matrices were used to establish the fish farm populations and any new stocks were probably selected among descendants of these small founder populations. Only wild populations and the populations from the fish farm in Santarém (PA) had satisfactory values of haplotype diversity, 0.99 and 0.957 , respectively.

Although some studies show a loss of genetic diversity in many fish farm stations throughout Brazil, our results revealed high haplotype diversity values in the tambaqui samples from the Betume and Itiúba fish farms (average: 0.909). J. P. Aguiar et al. (2013) also found high values of haplotype diversity in two tambaqui farms in the state of Pará $(h>0.838$ and $h>0.931)$, which the authors attributed to the introduction of new haplotypes from wild-caught individuals brought into captivity to renew stocks, but this did not seem to be the case in the other fish farms assessed. According to C. H. dos A. dos Santos et al. (2012), the loss of genetic diversity observed in captive populations is directly related to the size of the broodstock and the increase in inbreeding rates. The number of breeders in a stock can be highly variable (Weingartner \& Zaniboni, 2013) and may range from 50 to 1000 fish (Moreira, 2001). In Salminus brasiliensis (Cuvier, 1816) (Characiformes: Characidae), genetic diversity can be maintained with a number of breeders close to the minimum (50 fish) (Weingartner \& Zaniboni, 2013). In our study, the number of breeders in each farm was considerably higher, 200 in Itiúba and 1400 in Betume. Thus, the size of the broodstocks analyzed in the current study (Table 1) is unlikely to affect the genetic variability of the captive tambaqui populations, indicating that reproductive management has been effective in maintaining variability in the stock. The loss of genetic diversity between culture systems may be related to differences in reproductive management techniques, matrix selection and origin, and number of breeders (Hilsdorf \& Dergam, 1999), which can lead to, among other factors, increased inbreeding rates and directly affect production parameters and fish fillet quality.

Genetic variability was estimated using genetic parameter estimates and DNA polymorphism analysis (Table 1). The results showed high values for haplotype diversity $(h)$ and low values for nucleotide diversity $(\pi)$ in both localities considered separately and together, whereas the average number of pairwise nucleotide differences $(k)$ was higher in the Itiúba site and in both sites combined than in Betume (Table 1).

Genetic variability parameters $h$ and $\pi$ may indicate expansion after a period of low effective population size: rapid population growth enhances the retention of new mutations. According to Grant and Bowen (1998), the high $h$ and low $\pi$ for the tambaqui populations analyzed together or separately in our study indicate that they went through a population bottleneck (in this case, due to a founder event) followed by rapid population growth. The haplotype network (Figure 1) showing haplotype 11 (Hap_11) linked to both prevalent and non-prevalent haplotypes by only a few mutations is suggestive of this expansion (Grant \& Bowen, 1998). 


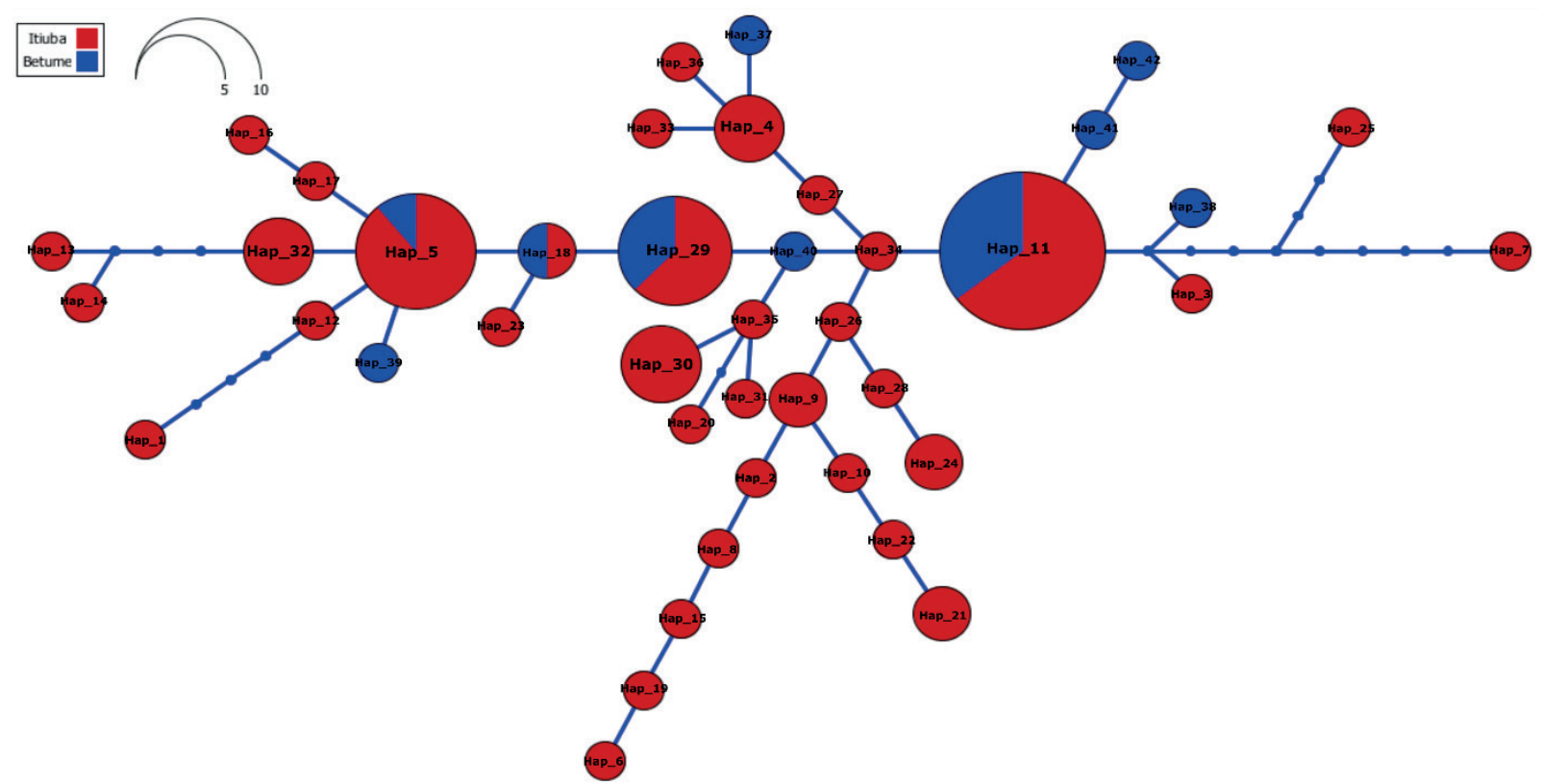

Figure 1. Haplotype distribution of Colossoma macropomum individuals from Betume, SE and Itiúba, AL, northeast Brazil.

Table 1

Genetic diversity parameters of Colossoma macropomum individuals from Betume, SE and Itiúba, AL, northeast Brazil

\begin{tabular}{lcccccccc}
\hline Locality & $\mathrm{N}$ & $\mathrm{H}$ & $\mathrm{ETA}$ & $h$ & $\pi$ & $k$ & Tajima & Fu \\
\hline Betume & 17 & 10 & 10 & $0.868 \pm 0.049$ & $0.0015 \pm 0.0011$ & 1.787 & -1.185 & $*-6.00479$ \\
Itiúba & 67 & 36 & 29 & $0.951 \pm 0.015$ & $0.0025 \pm 0.0015$ & 2.899 & -1.399 & $*-26.508$ \\
Total & 84 & 42 & 32 & $0.938 \pm 0.0165$ & $0.0023 \pm 0.0014$ & 2.711 & $*-1.528$ & $*-26.669$ \\
\hline
\end{tabular}

$\mathrm{N}$ : number of individuals, H: number of haplotypes, ETA - total number of mutations, $h$ : haplotype diversity, $\pi$ : nucleotide diversity, $k$ : mean of pairwise nucleotide differences, Tajima: Tajima's neutrality test, Fu: Fu's neutrality test. * Significant at $\mathrm{p}<0.05$.

The values of Tajima's $D$ test were negative and statistically significant $(\mathrm{P}<0.05)$ when the populations were analyzed together (Table 1), which is indicative of population expansion (Tajima, 1989). Considering both populations separately and together, the results of Fu's $F s$ test were also negative and statistically significant, indicating a possible expansion of the two tambaqui populations ( $\mathrm{Fu}, 1997)$, which is supported by their unimodal distribution curves (not shown).

AMOVA showed greater within- than betweenstock genetic variation (Table 2), whereas the $\mathrm{F}_{\mathrm{ST}}$ value (0.03) showed small genetic differentiation
(Wright, 1978). This greater variation within the stock can be explained by the presence of exclusive haplotypes in both populations, 26 in Itiúba and six in Betume.

Overall, results of Tajima's $D$ and Fu's Fs neutrality tests showed that the tambaqui populations of Itiúba and Betume are not in genetic equilibrium (Table 1). According to Tajima (1989) and Fu (1997), negative values for these two neutrality tests suggest that there is an excess of recent mutations and population growth or selection, which is consistent with results for genetic parameters $h$ and $\pi$. 
The high genetic variability in the tambaqui specimens analyzed in both fish farms, may be explained by the large number of breeders used by them, 200 in Itiúba (A. A. A. Albuquerque, personal communication, 16 May, 2020) and 1400 in Betume (A. H. G. Silva, personal communication, 16 May, 2020).

Knowledge of the genetic variability of aquaculture species is of great importance, especially in tambaqui, which is one of the most cultivated native fish species in Brazil. Although there is a good understanding of induced breeding techniques for a few fish species in the country, production losses still occur due to inadequate stock management. Knowledge of genetic diversity can help increase the productivity of fish stock because it gives producers greater control over the reproductive process to minimize inbreeding and avoid the mating of related individuals, which may lead to a decline in the fitness of the captive population, often resulting in the loss of the entire stock. Even though the tambaqui is native to the Amazon, it is farmed across the country with good productivity and has great market acceptance. However, some fish farmers have not been giving enough attention to the genetic variability of their broodstocks, leading to significant losses. According to Varela, Alves, Barroso and Tardivo (2015), tambaqui fry stations usually overlook information on the origin and genetic kinship of individuals when establishing a stock.

Tambaqui production has been increasing in Brazil over the last years and, according to Instituto Brasileiro de Geografia e Estatística [IBGE] (2018) the cultivation of this species was responsible for $19.7 \%$ of continental aquaculture production in 2018. Nevertheless, there is still a lack of information on genetic evaluation in breeding programs for tambaqui (Moraes et al., 2017). The management of genetic diversity in cultivated fish stocks of economic importance such as tambaqui is critical and can have direct implications on the quality of the products available to consumers.

Table 2

Analysis of molecular variance (AMOVA) of Colossoma macropomum individuals from Itiúba, AL and Betume, SE, northeast Brazil

\begin{tabular}{lcc}
\hline Source of the variation & Component of the variance & Percentage of the variation \\
\hline Between populations & 0.0448 & 3,24 \\
\hline Within populations & 1.3410 & 96,76 \\
\hline
\end{tabular}

Fst:0.03.

\section{Conclusions}

High levels of genetic diversity were found in the two tambaqui farms analyzed.

Broodstock size did not affect genetic variability and reproductive management has been effective in maintaining stock variability.

Knowledge of the genetic structure of tambaqui stocks is essential to maintain the quality of the product available to consumers in the lower São Francisco region.
Based on the high levels of genetic diversity found in the two fish farms in the lower São Francisco River, we encourage tambaqui farming stations across Brazil to implement a similar breeding management system.

Our findings show it is possible to support and maintain high genetic diversity in fish farms of the lower São Francisco River. However, studies with other molecular markers such as microsatellites are warranted, and it is important to continue to monitor 
the genetic diversity of tambaqui stocks while maintaining improvements in the management system.

\section{Acknowledgements}

The authors thank Alagoas Research Foundation (FAPEAL/CNPq - PPP - 01/2011) for financial support and CODEVASF Integrated Center of Itiúba $(\mathrm{AL})$ and the $4^{\text {th }}$ SR Betume (SE) for providing the tambaqui specimens. We also acknowledge the National Department of Works Against Drought (DNOCS) for providing literature on tambaqui farming and Dr. Izeni Pires Farias (UFAM) and Dr. Maria da Conceição Freitas dos Santos (UEA) for donating the primers.

\section{References}

Aguiar, J. da P., Fazzi Gomes, P. F., Hamoy, I. G., Santos, S. E. B. dos, Schneider, H., \& Sampaio, I. (2018). Loss of genetic variability in the captive stocks of Tambaqui, Colossoma macropomum (Cuvier, 1818) at breeding centres in Brazil, and their divergence from wild populations. Aquaculture Research, 49(5), 1914-1925. doi: 10.1111/are.13647

Aguiar, J. P., Schneider, H., Gomes, F., Carneiro, J., Santos, S., Rodrigues, L. R., \& Sampaio, I. (2013). Genetic variation in native and farmed populations of Tambaqui (Colossoma macropomum) in the Brazilian Amazon: regional discrepancies in farming systems. Anais da Academia Brasileira de Ciências, 85(4), 1439-1447. doi: 10.1590/0001-376520130007

Albuquerque, M. O., Silva, J. W. B., \& Kovács, G. (1991). Sobre o desenvolvimento do ovo e embrião do tambaqui, Colossoma macropomum CUVIER, 1818. (Boletim Técnico, n. 47/521/2). Fortaleza: DNOCS.

Araujo-Lima, C. A. R. M., \& Goulding, M. (1997). So fruitful fish: ecology, conservation, and aquaculture of the Amazon's Tambaqui. New York, NY: Columbia University Press.

Carvalho, J., $\mathrm{F}^{\circ}$. (2019). Os números da aquicultura brasileira em 2018. Panorama da Aquicultura, 29(174), 58-61. Recuperado em http:// panoramadaaquicultura.com.br/os-numeros-daaquicultura-brasileira-em-2018/
Clayton, D. A. (1982). Replication of animal mitochondrial DNA. Cell, 28(4), 693-705, 1982. doi: 10.1016/ 0092-8674(82)90049-6

Excoffier, L., \& Lischer, H. E. L. (2010). Arlequin suite ver 3.5: A new series of programs to perform population genetics analyses under Linux and Windows. Molecular Ecology Resources, 10(3), 564-567. doi: 10.1111/j.1755-0998.2010.02847.x

Faria, R. H. S. de, Morais, M., Soranna, M. R. G. de S., \& Sallum, W. B. (2013). Manual de criação de peixes em viveiro. Brasília: Codevasf.

Fazzi-Gomes, P., Guerreiro, S., Palheta, G. D. A., Melo, N. F. A. C. de, Santos, S., \& Hamoy, I. (2017). High genetic diversity and connectivity in Colossoma macropomum in the Amazon basin revealed by microsatellite markers. Genetics and Molecular Biology, 40(1), 142-146. doi: 10.1590/1678-4685gmb-2015-0222

Fontes, N. de A., Senhorini, J. A., \& Lucas, A. F. B. (1990). Efeito de duas densidades de estocagem no desempenho larval do paqui, Piaractus mesopotamicus (fêmea) (Holmberg 1887) X Colossoma macropomum (macho) (Cuvier 1818) em viveiros. (Boletim Técnico, 3). Pirassununga: CEPTA.

Fu, Y.-X. (1997). Statistical tests of neutrality of mutations against population growth, hitchhiking and background selection. Genetics, 147(2), 915925, 1997. Recuperado em http://filogeografia.dna. ac/ PDFs/Fu_97_F-sub-S_Test.pdf

Gomes, F., Schneider, H., Barros, C., Sampaio, D., Hashimoto, D., Porto-Foresti, F., \& Sampaio, I. (2012). Innovative molecular approach to the identification of the tambaqui (Colossoma macropomum) and its hybrids. Anais da Academia Brasileira de Ciências, 84(2), 5-8. doi: 10.1590/ S0001-376520120050000 25

Gomes, L. de C., Simões, L. N., \& Araújo-Lima, C. A. R. M. (2013). Tambaqui (Colossoma macropomum). In B. Baldisserotto, \& L. C. Gomes (Eds.), Espécies nativas para piscicultura no Brasil (pp. 177). Santa Maria, RS: Ed. UFSM.

Grant, W. S., \& Bowen, B. W. (1998). Shallow population histories in deep evolutionary lineages of marine fishes: insights from sardines and anchovies and lessons for conservation. Journal of Heredity, 89(5), 415-426. doi: 10.1093/jhered/89.5.415

Hall, T. A. (1999). BioEdit: a user-friendly biological sequence alignment editor and analysis program for Windows 95/98/NT.Version 7.2.5, last update 
(12/11/2013). Nucleic Acids Symposium Series, 41(1), 95-98. doi: 10.14601/Phytopathol_Mediterr$14998 \mathrm{u} 1.29$

Hilsdorf, A. W. S., \& Dergam, J. A. (1999). Depressão por endogamia: somente uma terminologia genética ou um fato na aquicultura. Panorama da Aquicultura, 9(55), 34-36. Recuperado em http://panoramada aquicultura.com.br/depressao-por-endogamia/

Instituto Brasileiro de Geografia e Estatística (2018). Produção da pecuária municipal 2018. Rio de Janeiro: IBGE. Recuperado de https://biblioteca. ibge.gov.br/visualizacao/periodicos/84/ppm_2018_ v46_br_informativo.pdf

Kozlov, A. M., Darriba, D., Flouri, T., Morel, B., \& Stamatakis, A. (2019). RAxML-NG: A fast, scalable, and user-friendly tool for maximum likelihood phylogenetic inference. Bioinformatics, 35(21), 4453-4455. doi: 10.1093/bioinformatics/btz305

Liu, Z. J., \& Cordes, J. F. (2004). DNA marker technologies and their applications in aquaculture genetics. Aquaculture, 238(1-4), 1-37. doi: 10.1016/j. aquaculture.2004.05.027

Lopera-Barrero, N. M., Ribeiro, R. P., Povh, J. A., Vargas, L., Fornari, D. C., Sirol, R. N., \& Rodríguez Rodríguez, M. del P. (2010). Diversidad genética de Brycon orbignyanus en el sistema reproductivo seminatural, utilizando o marcador RAPD. Zootecnia Tropical, 28(1), 73-82. Recuperado em http:// www.researchgate.net/publication/262477931 Diversidad_genetica_de_Brycon_orbignyanus_en_ el_sistema_reproductivo_semi-natural_utilizando_ el_marcador_RAPD

Lopera-Barrero, N. M., Rodriguez-Rodriguez, M. del P., Fornari, D. C., Resende, E. K. de, Poveda-Parra, A. R., Braccini,... Ribeiro, R. P. (2015). Genetic variability of broodstocks of Tambaqui (TeleosteiCharacidae) from the northeast region of Brazil. Semina: Ciências Agrárias, 36(6), 4013-4022. doi: 10. 5433/1679-0359.2015v36n6p4013

Melo, D. C., Oliveira, D. A. A., Ribeiro, L. P., Teixeira, C. S., Souza, A. B., Coelho, E. G. A.,... Teixeira, E. A. (2006). Caracterização genética de seis plantéis comerciais de tilápia (Oreochromis) utilizando marcadores microsatéllites. Arquivo Brasileiro de Medicina Veterinária e Zootecnia, 58(1), 87-93. doi: 10.1590/S0102-09352006000100013

Meyer, A. (1993). Evolution of mitochondrial DNA in fishes. In P. Hochachka, \& T. P. Mommsen (Eds.), Biochemistry and molecular biology of fishes (pp. 1-38). Amsterdam: Elsevier Science.
Ministério da Agricultura, Pecuária e Abastecimento (2019). No periodo de 2019/2020, pesca eaquicultura têm melhores condições de comercialização. Brasília: MAPA. Recuperado de https://www.gov. br/agricultura/pt-br/assuntos/noticias/melhorescondicoes-de-comercializacao-beneficiam-o-setorde-pesca-e-aquiculturaercializacao-beneficiam-osetor-de-pesca-e-aquicultura

Molle, F., \& Cadier, E. (1992). Manual do pequeno açude: construir, conservar e aproveitar pequenos açudes no nordeste brasileiro. Recife: SUDENE.

Moraes, A., Neto, Ayres, D. R., Streit, D. P., Jr., LoperaBarrero, N. M., Ferraz, P. B., F', Corrêa, R. A. C., $\mathrm{F}^{\circ}, \ldots$ Povh, J. A. (2017). Genetic diversity of tambaqui broodstocks in stock enhancement programs. Semina: Ciências Agrárias, 38(3), 16651670. doi: 10.5433/1679-0359.2017v38n3p1665

Moreira, H. L. M. (2001). Genética e melhoramento de peixes. In H. L. M. Moreira, L. Vargas, R. P. Ribeiro, \& S. Zimmermann (Eds.), Fundamentos da moderna aquicultura (pp. 135-147). Canoas: Ed. ULBRA.

Nelson, J. S., Terry, C. G., \& Mark, V. H. W. (2016). Fishes of the world (5a ed.). Hoboken, New Jersey: John Wiley \& Sons.

Overturf, K. (2009). Convergence of aquaculture and molecular biology. In K. Overturf (Ed.), Molecular research in aquaculture (pp. 1-13). Iowa: John Wiley \& Sons.

Page, R. D. M., \& Holmes, E. C. (1998). Molecular evolution: a phylogenetic approach. Oxford: Blackwell Science.

Porta, J., Porta, J. M., Martínez-Rodríguez, G., \& Alvarez, M. C. (2006). Genetic structure and genetic relatedness of a hatchery stock of Senegal sole (Solea senegalensis) inferred by microsatellites. Aquaculture, 251(1), 46-55. doi: 10.1016/j. aquaculture.2005.05.019

Povh, J. A., Ribeiro, R. P., Sirol, R. N., Streit, D. P., Jr., Lopera-Barrero, N. M., Vargas, L.,... Lopes, T. S. (2008). Diversidade genética de pacu do rio Paranapanema e do estoque de um programa de repovoamento. Pesquisa Agropecuária Brasileira, 43(2), 201-206. doi: 10.1590/s0100-204x200800020 0007

Queiroz, C. A. de, Souza, N. R., Silva, G. F. da, \& Inoue, L. A. K. A. (2016). Impacts of stocking on the genetic diversity of Colossoma macropomum in central Amazon, Brazil. Genetics and Molecular Research, 15(2), 1-9. doi: 10.4238/gmr.15027700 
Ribeiro, R. P., Rodriguez-Rodriguez, M. del P., Resende, E. K., Souza, F. P., Povh, J. A., PovedaParra, A. R.,... Lopera-Barrero, N. M. (2016). Genetic characteristics of Tambaqui broodstocks in the state of Rondônia, Brazil: implications on production and conservation. Semina: Ciências Agrárias, 37(4, Suppl. 1), 2375-2386. doi: 10.5433/1679-0359.2016v37n4Supl1p2375

Rogers, A. R., \& Harpending, H. (1992). Population growth makes waves in the distribution of pairwise genetic differences. Molecular Biology Evolution, 9(3), 552-569. doi: 10.1093/oxfordjournals.molbev. a040727

Rozas, J., Librado, P., Sánchez-Delbarrio, J. C., Messeguer, X., \& Rozas, R. (2010.). DnaSP v 5.10.01: a software for comprehensive analysis of DNA polymorphism data. Bioinformatics, 25(11), 1451-1452. Recuperado em http://www.ub.edu/ dnasp/index_v5.html

Salzburger, W., Ewing, G. B., \& Von Haeseler, A. (2011). The performance of phylogenetic algorithms in estimating haplotype genealogies with migration. Molecular Ecology, 20(9), 1952-1963. doi: 10.1111/j. 1365-294X.2011.05066.X

Santos, C. H. dos A. dos, Brito Leitão, M. A. de, Souza, C. F. S. de, Santana, G. X., Paula-Silva, M. de N., \& Almeida-Val, V. M. F. (2012). Genetic variability of wild and captivity populations of Colossoma macropomum (Cuvier, 1818). Acta Scientiarum. Biological Sciences, 34(2), 191-197. doi: 10.4025/ actascibiolsci.v34i2.7149

Santos, G. M., Ferreira, E. J. G., \& Zuanon, J. A. S. (2006). Peixes comerciais de Manaus (2a ed.). Manaus, AM: INPA.

Santos, M. C. F., Ruffino, M. L., \& Farias, I. P. (2007). High levels of genetic variability and panmixia of the tambaqui Colossoma macropomum (Cuvier, 1816) in the main channel of the Amazon River. Journal of Fish Biology, 71(Suppl. A), 33-44. doi: 10.1111/j.10 958649.2007.01514.X

Santos, M. C. F., Hrbek, T., \& Farias, I. P. (2018). A multilocus approach to understanding historical and contemporary demography of the keystone floodplain species Colossoma macropomum (Teleostei: Characiformes). Frontiers in Genetics, 9(263), 1-17. doi: 10.3389/fgene.2018.00263

Silva, C. A. da, \& Fujimoto, R. Y. (2012). A piscicultura familiar do tambaqui na região do Baixo São Francisco. Aracaju: Embrapa Tabuleiros Costeiros.
Sivasundar, A., Bermingham, E., \& Orti, G. (2001). Population structure and biogeography of migratory freshwater fishes (Prochilodus: Characiformes) in major South American rivers. Molecular Ecology, 10(2), 407-417. doi: 10.1046/j.1365294X.2001.01194.x

Tajima, F. (1989). Statistical method for testing the neutral mutation hypothesis by DNA polymorphism. Genetics, 123(3), 585-595. Recuperado em http:// www.ncbi.nlm.nih.gov/pmc/articles/PMC1203831/ pdf/ge1233585.pdf

Thompson, J. D., Higgins, D. G., \& Gibson, T. J. (1994). CLUSTALW: improving the sensitivity of progressive multiple sequence alignment through sequence weinhting, position-specific gap penalties and weigth matrix choice. Nucleic Acids Research, 22(22), 4673-4680. doi: 10.1093/nar/22.22.4673

Varela, E. S., Alves, A. L., Barroso, A. da S., \& Tardivo, T. F. (2014). Parentesco genético em reprodutores de tambaqui (Colossoma macropomum) baseado em marcadores de DNA: perspectivas de manejo genético na ausência de pedigree. Palmas: EMBRAPA Pesca e Aquicultura. Recuperado de https:// www.researchgate.net/publication/292152775 Parentesco_genetico_em_reprodutores_de_ tambaqui_Colossoma_macropomum_baseado_em marcadores_de_DNĀ_perspectivas_de_manejo_genetico_na_ausencia_de_pedigree_Serie_Embrapa ?channel $=\overline{\text { doi }} \&$ linkId $=56$ ab5 57 e08aed5a0135c0e63 \&showFulltext=true

Weingartner, M., \& Zaniboni, E., Fº (2013). Biologia e cultivo do dourado. In B. Baldisserotto, \& L. C. Gomes (Eds.), Espécies nativas para a piscicultura no Brasil (2a ed., pp. 245-281). Santa Maria, RS: Editora da UFSM.

Wright, S. (1978). Evolution and genetics of populations. Chicago: University of Chicago.

Wu, Y.-P., Xie, J.-F., He, Q.-S., \& Xie, J.-L. (2015). The complete mitochondrial genome sequence of Colossoma macropomum (Characiformes: Serrasalmidae). Mitochondrial DNA, 27(6), 40804081. doi: 10.3109/19401736.2014.1003853

Xin-Hong, G., Shao-Jun, L., \& Yun, L. (2004). Evidence for maternal inheritance of mitochondrial DNA in polyploidy fish of crosses by ATPase 8 and ATPase6 genes. Acta Zoologica Sinica, 50(3), 408-413.

Yan, J., Guo, X., Liu, S., Xiao, J., Liu, Z., Chen, Y., \& Liu, Y. (2009). Maternal inheritance in polyploid fish inferred from mitochondrial ATPase genes analysis. Progress in Natural Science, 19(6), 693-698. doi: 10.1016/j.pnsc.2008.10.004 
